\title{
STEAM EDUCATION AS A BENCHMARK FOR INNOVATIVE TRAINING OF FUTURE TEACHERS OF LABOUR TRAINING AND TECHNOLOGY
}

\author{
Vitaliy Hlukhaniuk \\ Vinnytsia Mykhailo Kotsiubynskyi State Pedagogical University, Ukraine \\ Viktor Solovej \\ Vinnytsia Mykhailo Kotsiubynskyi State Pedagogical University, Ukraine \\ Svitlana Tsvilyk \\ Vinnytsia Mykhailo Kotsiubynskyi State Pedagogical University, Ukraine \\ Iryna Shymkova \\ Vinnytsia Mykhailo Kotsiubynskyi State Pedagogical University, Ukraine
}

\begin{abstract}
The purpose of the article is to substantiate an innovative methodology for implementing the content of STEAM (science, technology, engineering, arts and math) education through the organization of creative projects of future teachers of labour training and technology.

The future teacher should be able to fulfil the tasks of integration of different subject areas, to use knowledge from different disciplines to describe the system of transformative activity; to make well-founded structural and technological decisions and put them into practice; to choose rational ways, to plan, predict and evaluate efficiency of transformative activity; to create spatial models of products or processes.

Investigating this problem, we used the methods of research: analysis and synthesis to clarify the basic concepts and categories of STEAM education; conceptual analysis for comparing traditional and STEAM-oriented approaches, curricula and programs, psychologicalpedagogical and scientific-methodical literature, materials of scientific-practical conferences on the problem of research, advanced innovative pedagogical experience.

The organization of project activities contributes to the formation of sustainable motivation in teaching the disciplines on which STEAM education is based. Creating a product from conception to implementation, students are aware of the integral theoretical and practical importance of knowledge in the natural-mathematical and technical disciplines of cycles of general and vocational training.
\end{abstract}

Keywords: creative projects, innovative education, STEAM-education, teacher of labour training and technology, technological processes. 
Hlukhaniuk et al., 2020. Steam Education as a Benchmark for Innovative Training of Future Teachers of Labour Training and Technology

\section{Introduction}

In today's socio-economic conditions, social life is changing rapidly. In turn, it provides for a continuous improvement of the education system and its components, principles and paradigms. The requirements for the professional competences of teachers are also constantly changing, as a major driving force of progressive change and cultivating citizens, who are capable of multiplying the state's achievements.

Knowledge is not the only measure of a person's professionalism in the 21st century. Creative, analytical, innovative thinking, an ability to work on projects in a team, information literacy and skills of effective use of information and communication technologies - this is an incomplete list of a modern successful person's characteristics. The transition to innovative education at European level involves the training of new generation specialists, capable of modern conditions of social mobility and mastering cutting-edge technologies. STEM (science, technology, engineering and math) learning heuristically reveals ways to identify and solve current educational problems (Polikhun, Slipukhina, \& Chernetskyi, 2017).

The purpose of the article is to substantiate an innovative methodology for implementing the content of STEAM (science, technology, engineering, arts and math) education through the organization of creative projects of future teachers of labour training and technology. System upgrade of the training for teachers of labour training and technology as well as determining the role and place of technological education is essential for the effective implementation of STEM training, since without the appropriate level formation of technological culture of all participants in the educational process is impossible to fully implement the STEM-oriented approach to learning.

\section{Research methodological foundations and methods}

Nowadays, Ukrainian teachers are working in the conditions of a new model of education, implementation of «New Ukrainian School» concept as well as introduction of new approaches in teaching, including STEM education. Hence STEM education is one of the factors behind the formation of an innovative teacher of labour training and technology, who is expected to have a set of general and professional competences that meets modern requirements (Kontseptsiia «Nova Ukrainska shkola», 2016). The STEM curriculum is based on the idea of teaching students a multidisciplinary and applied approach. Instead of studying each discipline individually, STEM integrates them into a single training scheme (Proekt kontseptsii STEM-osvity v Ukraini, 2017). 
However, the issues of integrated approach to STEM education in higher education institutions of Ukraine in the preparation of specialists of technological education, in particular teachers of labour education and technology, are not sufficiently addressed or just outlined.

While investigating this problem, we used the methods of theoretical and empirical research: analysis and synthesis to clarify the basic concepts and categories of STEM education; conceptual analysis for analogizing traditional and STEM-oriented approaches, curricula and programs, psychologicalpedagogical and scientific and methodical literature, materials of scientificpractical conferences on the problem of research, observation, questioning (interview, questionnaire), study of products of the activities of the subjects (creative and control works), study and generalization of pedagogical experience.

\section{Results and discussion}

Today's pedagogical research indicates that the rapid development of technology, determines the popularization and global perspective of such professions as software engineer, IT specialist, bio and nanotechnology specialists, etc. In the near future, there will be professions that are hard to imagine, all of which will be related to technology and high-tech manufacturing at the interface with the natural sciences. High-tech professionals will be especially needed (Perrault, 2016).

Modern education is not a transfer of knowledge from a teacher to a student, but also a consciousness expansion of a young generation and development vitally necessary skills. The core competencies that have been developed while teaching a complex of subjects in different educational institutions should be integrated into a system that can be used as a basis for further lifelong self-study. One of the current trends in innovative educational development is the STEM-oriented approach to learning (5 skills future teachers will need. The Global Education and Skills Forum, 2018).

According to D. Moye, technological education is a great format for integrating science, technology, engineering and mathematics (STEM), developing mathematical skills. However, the benefits of technological education are still unclear to the public (Moye, 2009).

While emphasizing the integrative role of technology teacher in reforming STEM education, M. Sanders, highlights that STEM is teachers of science, technology, mathematics - STEM educators, working in STEM education; The letter $\mathrm{T}$ (technology) in the STEM acronym is often mistaken for purely computer-based learning (author emphasis) (Sanders, 2009). 
Hlukhaniuk et al., 2020. Steam Education as a Benchmark for Innovative Training of Future Teachers of Labour Training and Technology

R. Bybee writes that present is shaping new circumstances, STEM education requires a stronger role for technology in school curricula. Technologies should be interpreted widely, not limited to, as information and communication technologies (Bybee, 2010).

In spite of this ambiguity, the concept of «STEM education» is being increasingly implemented in various educational programs in many countries. STEM centers are being created, and international conferences in this area are being held. The Ukrainian education system is involved in the implementation of the STEM-learning process, which combines interdisciplinary and projectbased approaches. The foundation of STEM training is the integration of natural sciences into technology, engineering and mathematics. Effective implementation of STEM training requires such design of curricula, when the teaching of natural and mathematical and technical disciplines as independent is abolished. While teaching technology in high school, STEM education demonstrates students an application of scientific and technical knowledge in real life through practical classes. During labour training, they develop and build technological products. Students study a particular project, resulting in prototypes of real objects. In addition, STEM programs differ by active communication and teamwork. At the project discussion stage, an open atmosphere is created for discussion and expression (Metodychni rekomendatsii shchodo vprovadzhennia STEM-osvity u zahalnoosvitnikh ta pozashkilnykh navchalnykh zakladakh Ukrainy na 2017/2018 navchalnyi rik, 2017).

STEM education is also called «learning the opposite», when the chain «from theory to practice» is usually the opposite: first - the game, inventing and mastering devices and mechanisms, and only then, in the process of this activity - mastering theory and new knowledge (D. Shulikin, 2015, p.8-9). Numerous scientific studies have proven that design technologies have a wide scope in various fields of knowledge, in the teaching of almost any subject, enhancing learning motivation, developing cognitive interest, creative skills, etc. (Honcharova, 2015).

Studying the scientific works on design technologies development as well as observing the educational process of teacher training of labour education and technology at the university convinces us that project technology has wide pedagogical possibilities, promotes deep program acquisition, effective organization of educational and cognitive activity, formation of competences to use in practical activity learning. forming, in fact, the project competence of the individual (Solovei, 2008).

Based on the analysis of theoretical and methodological foundations of creating an innovative model of STEM education, researchers have identified approaches to the implementation of the model of STEM education in a pedagogical university. Such principles are considered to be the transition to 
innovative learning through the use of project-oriented learning methods. Teachers claim that the scientific and methodological principles of organization of STEM-education, project-oriented technology training and projecttechnological activity are common. In the process of technological development, students' creative thinking is formed, their ability to solve problems in different spheres of life. The formation and development of design and technological competence is the goal of the technology industry.

STEM education is a benchmark for innovative technological training of future teachers of labour education and technology in the integrated system of technological education of natural-mathematical and vocational-oriented disciplines. To implement STEM education in pedagogical higher education institutions, scientists have a special role to play in project-oriented teaching methods that involve students in the process of forming general and professional competences through research activities based on solving complex technical issues (Shymkova, Tsvilyk, \& Harkushevskyi, 2019).

According to the idea of STEM education, students at school and in higher education are learning to apply knowledge of different sciences, technologies, engineering and creative thinking to solve real-life problems. Adding the arts to STEM with the transition to STEAM involves incorporating creative thinking and applied arts into real situations. The acronym A (Arts) stands for creative, artistic disciplines. It is worth noting that the basic principles and practices of STEM and STEAM (STEM with a "creative» component) are the same - an integration of the foundations of science, technology, engineering, arts and mathematics. By «Arts» in the concept of implementing STEAM training in the system of training teachers of labour education and technology, first of all, we understand the teaching of the basics of modeling, artistic and technical design, graphic and industrial design, etc. The use of the STEAM approach in the training of future teachers of labour training and technology promotes awareness of the multilevel connections between various aspects of modern product production or service delivery, and an understanding the role of design. It is in the design that combines art and subject matter and scientifically sound engineering practice.

In secondary school, labour education lessons have a strong potential for integration with other school subjects. The teacher of labour education and technology together with the teachers of other subjects can prepare and conduct binary lessons on different topics. Applied orientation of labour education in secondary school (grades 5-9) and technology in high school (grades 9-11) allows to find many topics for conducting binary lessons and integrating knowledge in various subjects to solve practical problems. For instance, these can be binary lessons in labour education and mathematics (learning certain rules of mathematics and their practical application in solving specific practical 
Hlukhaniuk et al., 2020. Steam Education as a Benchmark for Innovative Training of Future Teachers of Labour Training and Technology

problems in labour education), binary lessons in labour education and physics (study of physical laws and their incorporation in the process of design, manufacture, decoration of products). Common topics of labour education and the Ukrainian language, chemistry, computer science are quite likely. For example, when designing an explanatory note to a project.

In order to attract students to the practical activity, the teacher of labor training and technology expands the range of organizational forms, teaching methods, ways of educational interaction and gives a certain priority to the acquisition of educational material in the process of interactive lessons: excursions, quests, competitions, festivals, hackathons, workshops, etc. (STEMosvita. Instytut modernizatsii zmistu osvity, 2019).

The effectiveness of implementing STEM and STEAM education is largely determined by the competence and scientific as well as methodological level of professional activity of scientific and pedagogical staff, as they actively use the latest pedagogical approaches in teaching and evaluating the results of cognitive activities of future educators, innovative interdisciplinary teaching practices with a focus on developing the research competencies of university students (Polikhun, Slipukhina, \& Chernetskyi, 2017).

Participation in various activities of regional, national, international levels contributes to the development of professional competence of teaching staff: scientific conferences, seminars, webinars, STEM festivals, competitions, classes at the web-STEM school «STEM teacher education» and more. At such events, educators not only gain new knowledge, access to new resources, but also have the opportunity to present their own achievements and share new thoughts, ideas, experiences. Teachers, according to the vector of their professional growth, need to use all proposals and join projects implemented not only by state educational institutions, but also by public, international (grant), commercial (Honcharova, 2015).

The organization of project activities of future teachers of labour training and technology contributes to the formation of sustainable motivation in the discipline of cycles of general and labour training on which STEM education is based. Creating a product from conception to realization, students are aware of the integral theoretical and practical importance of knowledge in the natural and mathematical and technical disciplines of the cycles of general and labour training. STEM education has a considerable potential for the creative initiative of the future teacher of labour training and technology and facilitates his active participation in the formation of general and professional competences defined by the educational and labour training program.

In accordance with certain requirements of selection of design objects, we offer some original creative tasks that can become interesting and useful to the teachers, who design the content of educational subjects of technological cycle 
(processing of structural materials, technological workshop, materials science and technologies of production of structural materials), graphic disciplines (Descriptive Geometry and Drawings, Computer Graphics, Fundamentals of Design and Modeling) in the training of a teacher of labour training and technology. It is also important to familiarize yourself with the tasks of practitioners in schools and out-of-school education and ordinary citizens who will be able to design, manufacture and use artistic and technical products in everyday life (Solovei, 2008).

1. Candlestick project «New Year's pyramid» (Fig. 1). Candlesticks and candles play an important role in creating a certain mood, and it often not only complements the candle, but also emphasizes the beauty of the flame, its decorative function. Expensive silver and bronze forged candlesticks have always been the pride of their owners. However, the current life trends make its adjustments to the situation around us. The roles and attitudes of usual things change. So the massive classic candlesticks giving way to a small and mobile, created for a specific occasion, specific decor of the table and room. It is easy to make such a candlestick of the most ordinary materials; it will be a good decoration. It is thanks to the candlestick that we, being in the heart of the metropolis, can return to the bosom of nature for a while and feel a mystical connection with the spirit of fire.

The analysis of variants of articles-analogs of candlesticks and combination of the best features of the chosen variant of construction allows to offer the final variant. This design object combines scientific, technical and artistic aspects, allowing the artist to realize his or her own creative potential.

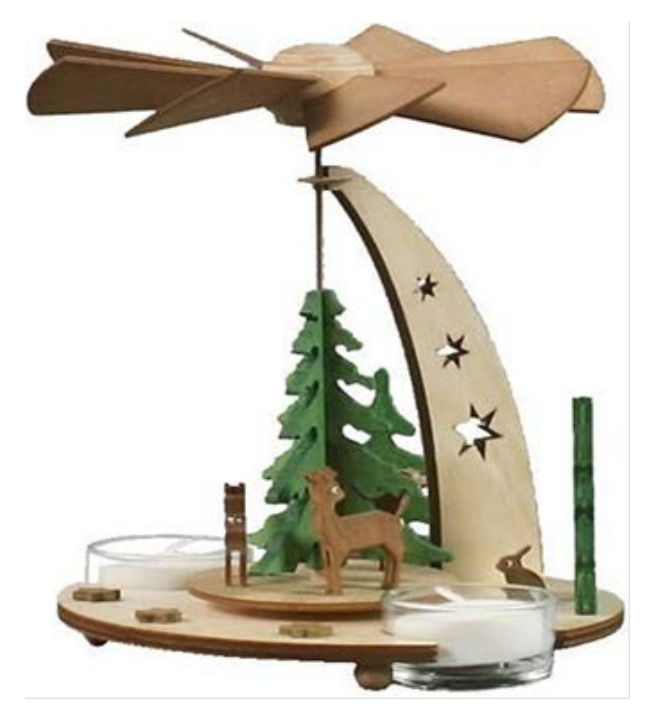

Figure 1 Candlesticks «New Year's pyramid» 
Hlukhaniuk et al., 2020. Steam Education as a Benchmark for Innovative Training of Future Teachers of Labour Training and Technology

A Christmas composition and tea candles are affixed to the wooden stand. In order to make the object of the project dynamic, it is possible to make a moving wooden ring on which it is advisable to place Christmas symbols (Christmas tree, snowman, Santa, deer). The wooden ring («scene») rotates from the air screw that connects the axis. The work of this luminaire is based on the phenomenon of convection, as a type of heat transfer, where heat is transported by heated jets of gas or liquid. In our case, the air heated by the tea candles rises and rotates the air screw.

2. Desk lamp project. The problem of unnecessary or old things arises in every home. Someone gives them to other people, takes them to church, sells them for resale. More often, unnecessary things are stored at home, taken to farms, thrown into the trash. But they can be beneficial if approached creatively. So in our case, it is a glass cylindrical vase in which the edge was damaged. There was a creative idea - to give a second life to unnecessary things. To do this, we have to cut the damaged edge and bottom of the vase, the cylinder of which will serve as the glass base of the lamp. On the table lamp it is offered to place an image of Vinnytsia Mykhailo Kotsiubynskyi State Pedagogical University and the sights of Vinnytsia in various techniques, which is expected to complement the interior of the room (Fig. 2).

The proposed variant of the project is a lamp (Fig. 2) having a glass cylinder 2 painted with stained-glass paints and fixed on a wooden stand 3 . The upper part of the cylinder is covered by a frame-ring 1 . The wooden stand and the frame-frame are decorated with a Petrykivka painting. A paper cylinder (Fig. 2, c) is inserted into the middle of the glass cylinder, which is decorated with a vinyl mount (Fig. 2, d). You can move a paper cylinder to make the design object more dynamic.

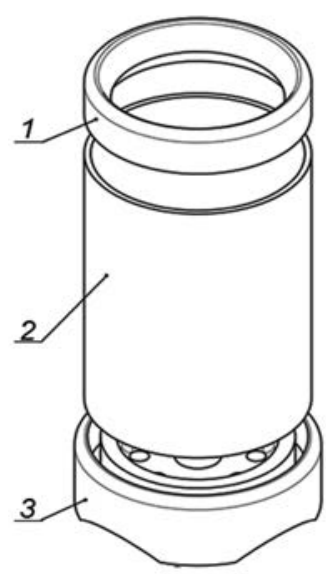

a)

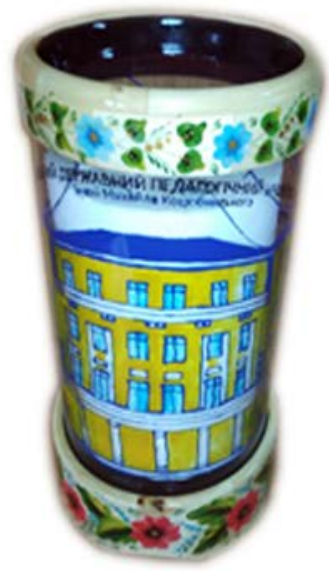

b)

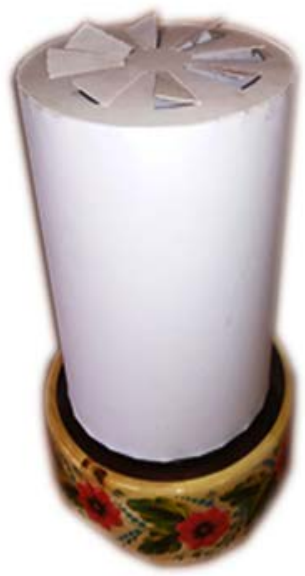

c)

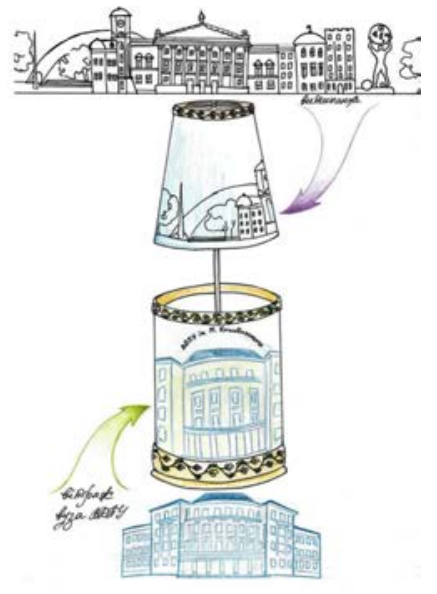

d)

Figure 2 The desk lamp 
The work of this lamp is based on the phenomenon of convection, when the air heated by a light bulb rises upwards and rotates the air screw (propeller) on which the paper cylinder is fixed.

\section{Conclusions}

Studies show that designing is one of the effective and relevant teaching methods in school-based training and professional training at a higher education institution. In this case, STEAM education is an effective benchmark for innovative technological training of future teachers of labour training as well as general and professional technological competences of students, formed during the integrated project technology training by means of STEAM-education. We have proposed a set of general and professional technological competencies of future teachers of labour training and technology, such as:

\section{General competencies:}

- the ability to learn throughout life in the context of continuing professional training and social life, to improve and develop one's intellectual and cultural background with a high level of independence;

- $\quad$ the ability to analyse, synthesize, critically and self-critically evaluate a situation or task in order to identify ways to address and work out a solution;

- $\quad$ the ability to make management decisions; to perceive, analyse and implement managerial innovations in professional activity;

- $\quad$ the ability to use modern information technologies to solve various problems in educational and practical activity, to work with professional information, to act creatively and systematically to think, to introduce modern scientific data into practical activity;

- the ability to think technically and to represent technical and technological objects and systems.

\section{Professional competencies:}

- $\quad$ knowledge of the structure, the way it works and purpose of working as well as power machines, information and cybernetic systems, their technological functions;

- $\quad$ the ability to understand, explain and perform technological processes in different industries;

- $\quad$ the ability to effectively apply and adapt natural and mathematical knowledge in the design and modelling of technological processes and pedagogical processes of secondary education; 
Hlukhaniuk et al., 2020. Steam Education as a Benchmark for Innovative Training of Future Teachers of Labour Training and Technology

- the ability to perform and organize the processing of structural materials, to artistic and technical creativity, decorative and applied art;

- $\quad$ the ability to help the student understand their needs, meet them, teach self-care, healthy lifestyles, safety and health requirements;

- $\quad$ the ability to perform research activities in the fields of engineering and technology, pedagogy and psychology, technological and vocational education.

The organization of project activities of future teachers of labour training and technology contributes to the formation of sustainable motivation in teaching the disciplines the STEM education is based on. Creating a product from concept to realization, students are aware of the integral theoretical and practical importance of knowledge in the natural-mathematical and technical disciplines of the cycles of general and labour training. STEAM education accumulates considerable potential for the creative initiative of the future teacher of vocational training and technology and promotes his active participation in the formation of general and professional competences determined by the educational and professional training program.

Unlike traditional teaching models, educators using the STEAM system integrate disciplines, using the dynamic synergy between the modeling process and the content of mathematics and other sciences, to blur the lines between modeling, artistic and mathematical thinking. Thanks to this holistic approach, both hemispheres of the brain develop simultaneously.

Not only the STEAM projects teach future teachers of labour training and technology to think critically, solve problems creatively. They prepare them for the training of students who will be employed by new dynamic sectors of social production. The formation of such general and professional competences of the future teacher is an important task of the educational and professional training program in the higher education institution, the integral purpose of which is the training of specialists who can further fulfill the professional functions of the teacher of labour training and technology and carry out educational, methodical, teaching, teaching harmonious personal development, formation of necessary competences and preparation for active employment of high school students.

\section{References}

5 skills future teachers will need. The Global Education \& Skills Forum. (2018). Retrieved from https://www.educationandskillsforum.org/news-blogs/5-skills-future-teacherswill-need

Bybee, R.W. (2010). Advancing STEM Education: A 2020 Vision. Technology and Engineering Teacher, 70, 30-35. 
Metodychni rekomendatsii shchodo vprovadzhennia STEM-osvity u zahalnoosvitnikh ta pozashkilnykh navchalnykh zakladakh Ukrainy na 2017/2018 navchalnyi rik. (2017). [Guideline for the implementation of STEM-education in secondary and extracurricular educational institutions of Ukraine for the 2017/2018 academic year]. Retrieved from https://drive.google.com/open?id=0B3m2TqBM0APKekwtZFdhWXJuODg

Moye, J.J. (2009). Technology education teacher supply and demand - A critical situation. The Technology Teacher, 69(2), 30-36.

Honcharova, N.O. (2015). Profesiina kompetentnist vchytelia u systemi navchannia STEM [Teacher professional competence in the STEM education system]. Naukovi zapysky Maloi akademii nauk Ukrainy [Scientific notes Minor Academy of Sciences of Ukraine], 7, 141-147.

Kontseptsiia «Nova Ukrainska shkola» [«New Ukrainian School» Concept]. (2016). Retrieved from https://www.kmu.gov.ua/storage/app/media/reforms/ukrainska-shkolacompressed.pdf

Perrault, T. (2016). Digital Companies Need More Liberal Arts Majors. Harvard Business Review, Blog. Accessed January 29, 2016. Retrieved from https://hbr.org/2016/01/digital-companies-need-more-liberal-arts-majors

Proekt kontseptsii STEM-osvity v Ukraini [Draft concept of STEM education in Ukraine]. (2017). Retrieved from http://mk-kor.at.ua/STEM/STEM_2017.pdf

Polikhun, N.I., Slipukhina, I.A., \& Chernetskyi, I.S. (2017). Pedahohichna tekhnolohiia STEM yak zasib reformuvannia osvitnoi systemy Ukrainy [STEM pedagogical technology as a means of reforming Ukraine's education system]. Osvita ta rozvytok obdarovanoi osobystosti [Education and Development of Gifted Personality], 3(58), 5-9.

Sanders, M. (2009). STEM, STEM education, STEMmania, The Technology Teacher, 68(4), $20-26$.

Shulikin, D. (2015). STEM-osvita: hotuvaty do innovatsii [STEM Education: Prepare for Innovation]. Osvita Ukrainy [Education of Ukraine], 26(1437), 8-9. Retrieved from http://lib.pedpresa.ua/wp-content/uploads/2015/08/26-2015_osvita_ukr-inet.pdf

Shymkova, I.V., Tsvilyk, S.D., \& Harkushevskyi, V.S. (2019). Modernizatsiia profesiinoi i tekhnolohichnoi pidhotovky maibutnikh pedahohiv u konteksti rozvytku STEAM-osvity [Modernization of professional and technology training for intending teachers in the context of STEM-education development]. Problemy pidhotovky suchasnoho vchytelia: zbirnyk naukovykh prats Umanskoho derzhavnoho pedahohichnoho universytetu imeni Pavla Tychyny [Problems of Modern Teacher Training], 1(19), 152-159.

Solovei, V.V. (2008). Obiekty proektnoi diialnosti v praktychnii pidhotovtsi maibutnikh vchyteliv trudovoho navchannia [Objects of project activity in practical training of future teachers of vocational training]. Trudova pidhotovka $v$ zakladakh osvity [Work training in educational institutions], 4(56), 46-49.

STEM-osvita. Instytut modernizatsii zmistu osvity (2019). [STEM education. Institute of education content modernization]. Retrieved from https://imzo.gov.ua/stem-osvita/ 